\title{
The Autoregressive Distributed Lag Model to Analyze Soybean Prices in Indonesia
}

\author{
Mahjus Ekananda ${ }^{1, *}$ and $T$. Suryanto ${ }^{2}$ \\ ${ }^{1}$ Faculty of Economy and Bussines, University of Indonesia, 16424, Indonesia \\ ${ }^{2}$ IAIN, Indonesia
}

\begin{abstract}
The main objective of this study was to observe factors that affecting domestic soybean prices, including government intervention through BULOG. By using Bound Testing Cointegration method with ARDL approach. In the short term the world soybean price variables in the t-period and exchange rate affect the domestic soybean prices positively and significantly. The variable volume of soybean imports, GDP, and the role of BULOG as sole importer in the t-period does not affect the domestic soybean price significantly. In the long run, the t-period import tariff has a negative and significant effect.
\end{abstract}

\section{Background}

Food has a very important role because it is one of the primary human needs. The importance of food can be seen from the concept of food security. The concept of food security has three interrelated dimensions consisting of food availability, community accessibility to food, and stability of food prices [1]. The concept is in accordance with the World Health Organization (WHO) which defines three main components of food security consisting of availability, accessibility, and food utilization which then the Food and Agriculture Organization (FAO) added a fourth component, namely the stability of the three components in a long period. Thus, it can be concluded, this food security is not only seen from the affordability physically but also in terms of price and stability of both components.

The stability of food prices is definitely one of the focus of every country. However, in reality, world food prices experienced a fairly high fluctuation, especially in 2007 to 2008 that caused by the international food crisis [19]. Some of the food commodities affected are sugar, wheat, milk, meat, corn, and soybeans [8]. While in some Asia Pacific countries there is an increase in the price of rice (UN-ESCAP, 2011). This condition can be seen in Fig. 1 which shows a dramatic increase in world food prices since 2007 and started to decline in the second half of 2008 and then increased again in 2009 and showed a significant decline in 2010 .

The fluctuation of commodity price which often become public attention is rice, corn, soybean, wheat flour, sugar, cooking oil, onion, chilli, egg, and milk [17]. Therefore, the

\footnotetext{
* Corresponding author: $\underline{\text { m.ekananda@gmail.com }}$
} 
government must control the price of these commodities to be affordable by all levels of society.

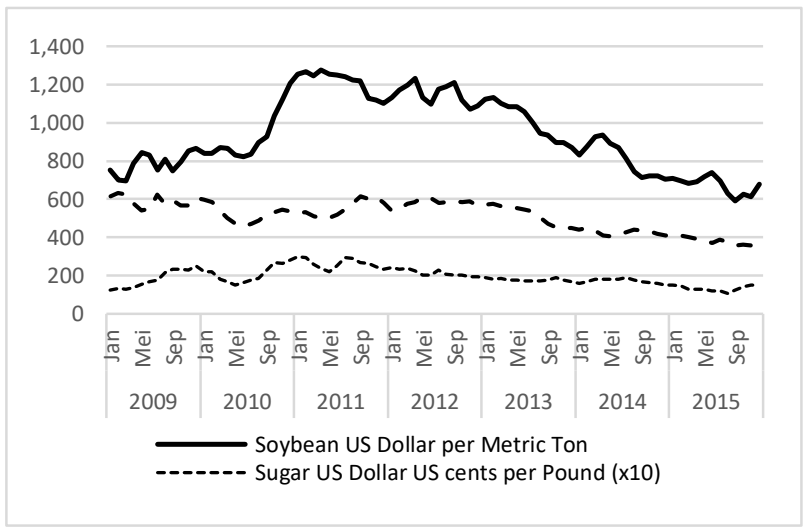

Fig. 1. Sugar World Price, Rice and Soybean Period January 2009 - December 2015.

Sources: IFS CD-ROM

Soybean is the most important food commodity after rice and corn which have strategic position in all national food policy because it is the raw material of daily staple food of most people of Indonesia that is Tofu and Tempe [18]. Fig. 2 shows the price of food in the country shows an increasing trend, although fluctuations in domestic food prices are not as sharp as world food prices, but quite unsettling the public.

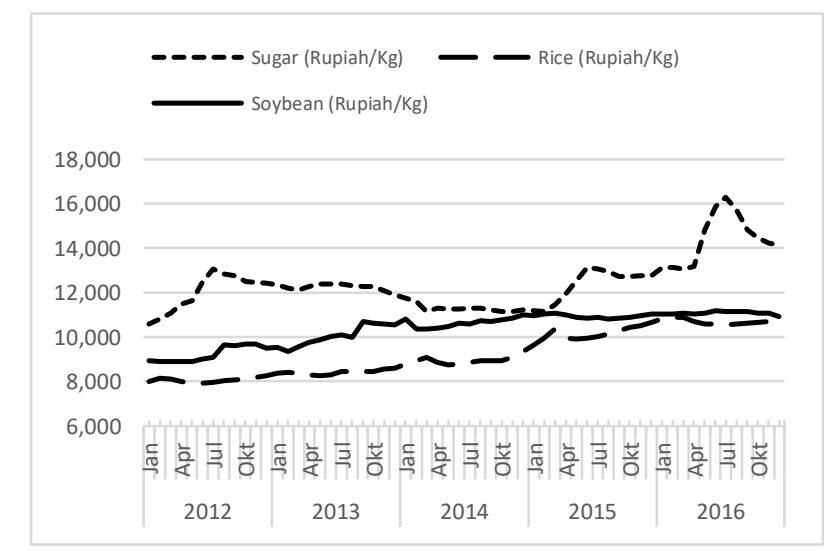

Fig. 2. Average Retail Price of Sugar, Rice and Soy Commodities, January 2012- Dec 2016.

Source: BPS and Ministry of Trade Sources: IFS CD-ROM

Fig. 3 shows a high increase in soybean prices since the end of 1997 and began to fall in the second half of 1999. Then there was an increase in early 2000 and a relatively large 
decline in early 2003. However, there was a sharp increase in 2008 and has continued to increase since then until now.

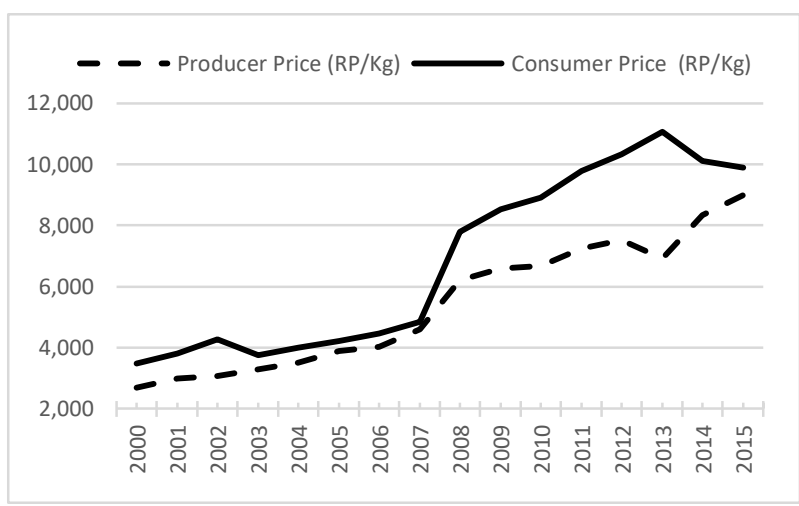

Fig. 3. Average Producer Price and Consumer Price of Soybean in Indonesia.

Source: Central Bureau of Statistics, 2015.

Table 1 shows the deficit of domestic soybean supply that must be met from import. There is a considerable increase in consumption in 2008 - 2012, placing Indonesia in the top ten soybean importers in the world. Nevertheless, the average import of Indonesia is only $2 \%$ of world imports while China is $49 \%$. In addition, more than $95 \%$ of Indonesia's soybean imports are from the United States and only about 3\% are obtained from Brazil. Thus, it can be said that the price of Indonesian soybean will be greatly influenced by US soybean prices.

Table 1. Production, Consumption, Bid Deficit, and Import Soybean in Indonesia Source: BPS and Ministry of Trade (2016). Note: *) is a proxy number

\begin{tabular}{|c|c|c|c|c|}
\hline Year & $\begin{array}{c}\text { Production } \\
\text { (Tons) }\end{array}$ & $\begin{array}{c}\text { Consumption * } \\
\text { (Tons) }\end{array}$ & $\begin{array}{c}\text { Deficit } \\
\text { (Tons) }\end{array}$ & $\begin{array}{c}\text { Import } \\
\text { (Tons) }\end{array}$ \\
\hline 2008 & 775,710 & $2,147,782$ & $1,372,072$ & $1,169,016$ \\
\hline 2009 & 974,512 & $2,288,686$ & $1,314,174$ & $1,314,620$ \\
\hline 2010 & 907,031 & $2,647,151$ & $1,740,120$ & $1,740,505$ \\
\hline 2011 & 851,286 & $2,781,533$ & $1,930,247$ & $2,088,616$ \\
\hline 2012 & 843,153 & $2,846,461$ & $2,003,308$ & $1,921,207$ \\
\hline 2013 & 791,334 & $2,990,961$ & $2,199,627$ & $1,774,252$ \\
\hline 2014 & 783,774 & $3,060,778$ & $2,277,004$ & $1,922,777$ \\
\hline 2015 & 776,286 & $3,132,224$ & $2,355,938$ & $1,639,104$ \\
\hline
\end{tabular}

Fulfillment of food can be done with domestic production and import. However, data show that the overall increase in soybean production in the period 2004 to 2013 is below a hundred thousand tons (Table 2). With the increasing demand for soybean commodities while domestic production is insufficient, then to cover the shortage the government takes import policy. Table 2 shows a considerable increase in soybean imports in the last ten years.

Table 2. Comparison of Productio Domestic and Soybean Imports in Indonesia Source: BPS and Ministry of Trade 


\begin{tabular}{|c|c|c|}
\hline Year & $\begin{array}{c}\text { Domestic production } \\
\text { (Tons) }\end{array}$ & $\begin{array}{c}\text { Import Volume } \\
\text { (Tons) }\end{array}$ \\
\hline 2004 & 723,483 & $1,115,793$ \\
\hline 2005 & 808,353 & $1,086,178$ \\
\hline 2006 & 747,611 & $1,132,144$ \\
\hline 2007 & 592,534 & $1,411,589$ \\
\hline 2008 & 775,710 & $1,169,016$ \\
\hline 2009 & 974,512 & $1,314,620$ \\
\hline 2010 & 907,031 & $1,740,505$ \\
\hline 2011 & 851,286 & $2,088,616$ \\
\hline 2012 & 843,153 & $1,921,207$ \\
\hline 2013 & 803733 & $1,774,252$ \\
\hline 2014 & 772183 & $1,922,777$ \\
\hline 2015 & 747586 & $1,639,104$ \\
\hline
\end{tabular}

The import policy can be accepted as one of the short-term solutions to reduce the effects of demand pressure on inflation. However, in the long run the import policy is known to have dragged Indonesia into various issues such as the potential of food cartel, import dependency, and inflation which is quite high due to the impact of rising international food prices. Fig. 4 shows that before 1999, the average volume of Indonesian soybean imports was only about 50,000 tons while after 1999 the average increased to about 150,000 tons. This indicates that when soybean imports are monopolized by BULOG, import volume is relatively lower compared to when soybean imports are handed over to private importers. The same is true for domestic soybean prices, which show a relatively more stable graph when the soybean import is monopolized by BULOG.

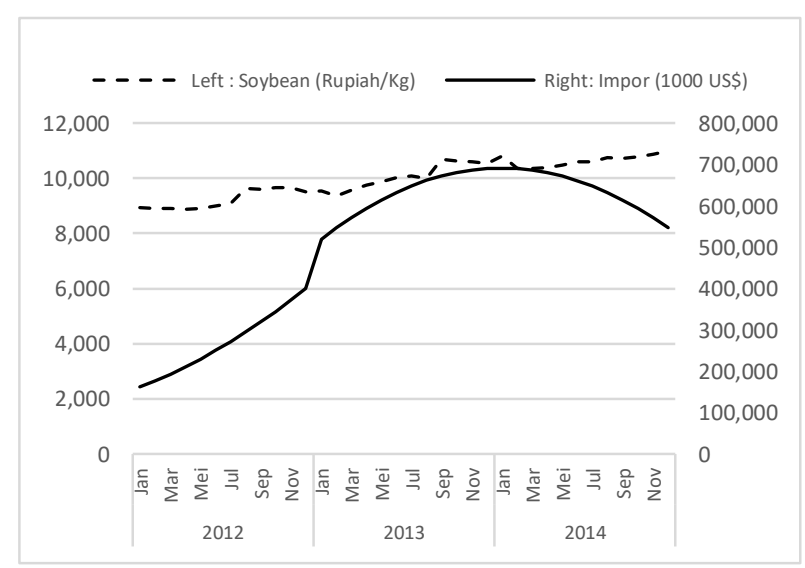

Fig. 4. Retail Price Trend and Import Volume of Indonesian Soybean, January 2012 - December 2014. Source: BPS and Ministry of Trade (processed)

The existence of dependence on food imports in Indonesia cannot be denied anymore. This condition can be shown from the Import Dependency Ratio (IDR) of food products especially for rice, beef, soybeans and sugar in Indonesia presented in Table 3.

Table 3. Import Dependency Ratio (IDR) of Food Products Indonesia Year 2008-2012. Source: DG of Livestock, Ministry and BPS, processed BP2KP, Ministry of Trade. Note: *) until October 2012 


\begin{tabular}{|l|r|r|r|r|r|}
\hline \multirow{2}{*}{ Commodity } & \multicolumn{6}{|c|}{ IDR (\%) } \\
\cline { 2 - 6 } & $\mathbf{2 0 0 8}$ & $\mathbf{2 0 0 9}$ & $\mathbf{2 0 1 0}$ & \multicolumn{1}{|c|}{$\mathbf{2 0 1 1}$} & \multicolumn{2}{c|}{$\mathbf{2 0 1 2}$} \\
\hline Rice & 1.2 & 1.0 & 2.3 & 7.9 & $5.8^{*}$ \\
\hline Beef & 10.4 & 14.2 & 17.2 & 12.2 & 18.45 \\
\hline Soybean & 60.1 & 57.4 & 65.8 & 71.1 & 71.46 \\
\hline Sugar & 34.4 & 51.3 & 52.3 & 60.3 & $65.6^{*}$ \\
\hline
\end{tabular}

From the table, it can be seen that IDR in the four commodities tends to increase from 2008-2012 and the highest ratio is found in soybean and sugar commodities which reach more than $60 \%$. However, the ratio of import dependence is relatively larger on soybean commodity than sugar. The high ratio indicates that domestic soybean availability from domestic production is relatively smaller compared to sugar and on the contrary the fulfillment of national soybean consumption from import is relatively higher in soybean compared to sugar. It also implies that soybean commodity prices are relatively more vulnerable to the effects of international price fluctuations.

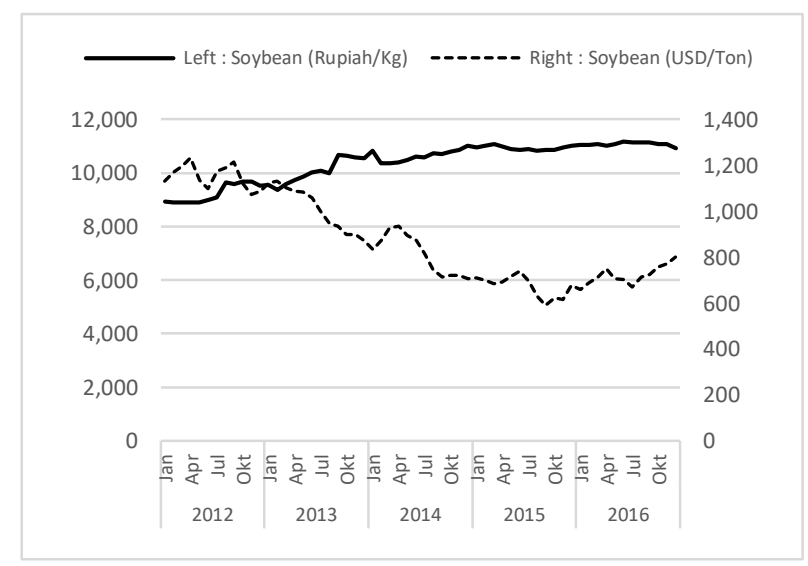

Fig. 5. Indonesia Soybean Retail Price Trend and Soybean Prices of the World Period January 2012December 2016. Source: BPS and IFS CD-ROM

Fig. 5 shows that when BULOG is still a single importer, soybean prices tend to be more stable and unaffected by international soybean prices. However, after soybean imports were handed over to private importers, soybean prices tend to be more fluctuative and show price trends that are rising faster than before and tend to follow the world soybean price movements especially during world soybean price spikes.

This research is expected to provide benefits in the academic world as well as input for policy makers to develop more targeted policies in order to stabilize soybean prices. In this research, dummy variable of BULOG role is used to stabilize soybean price when becoming single importer and after not becoming a single importer. The stable definition meant in this research is BULOG able to intervene soybean price when price increase by increasing stock, for example through market operation. Thus, BULOG's role as a single importer of domestic soybean price is expected to be negative. Means that, at the time BULOG still be a single importer, namely in the period December 1993 - September 1998 then BULOG able to intervene in increased prices and lower it.

\section{Literature Review}


Fig. 6 shows that if there is no international trade, the equilibrium condition in Indonesian domestic market will occur at point A with the soybean price of PA and the amount of soybean demanded will be equal to the quantity of goods offered ie QA. Meanwhile, in foreign markets or referred to as 'rest of the world' (ROW), equilibrium conditions are at point $\mathrm{B}$ with the price of $\mathrm{PB}$ soybeans and the amount of soybean demanded will also be equal to the number of soybeans offered on QB. A country will import a commodity if its domestic price is above world price. If the condition is met then domestic economic actors have an incentive to buy imported goods (Pugel, 2004). If economic agents import soybeans, the total domestic soybean supply will rise and lower soybean prices in the domestic market resulting in excess demand. Suppose that domestic soybean price drops to PF, local production will decline to QSF1, the number of domestic demand rises to QDF1, and there are imports of QDF1 - QSF1. Meanwhile, in the ROW market, if the price is above the PB, say in PF, then the ROW producer will produce more that becomes QSF2, the ROW demand will decrease to QDF2, so there is an excess supply of QSF2-QDF2. Excess supply is what will be exported. Thus, international equilibrium will form at point $\mathrm{E}$ at the price level of $\mathrm{PF}$ and the quantity of goods demanded is equal to the quantity of goods offered by QF.

Fig. 6. Relation of Domestic and Domestic Soybean Prices. Source [16]

$$
\begin{aligned}
& \text { Soybean Market } \\
& \text { Indonesia }
\end{aligned}
$$

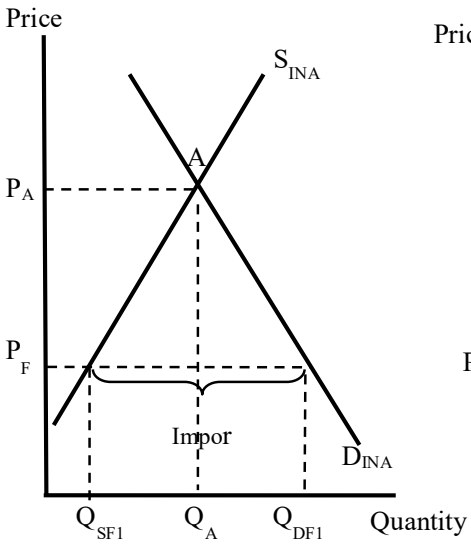

\section{Soybean Market} International
Soybean Market Rest of the World
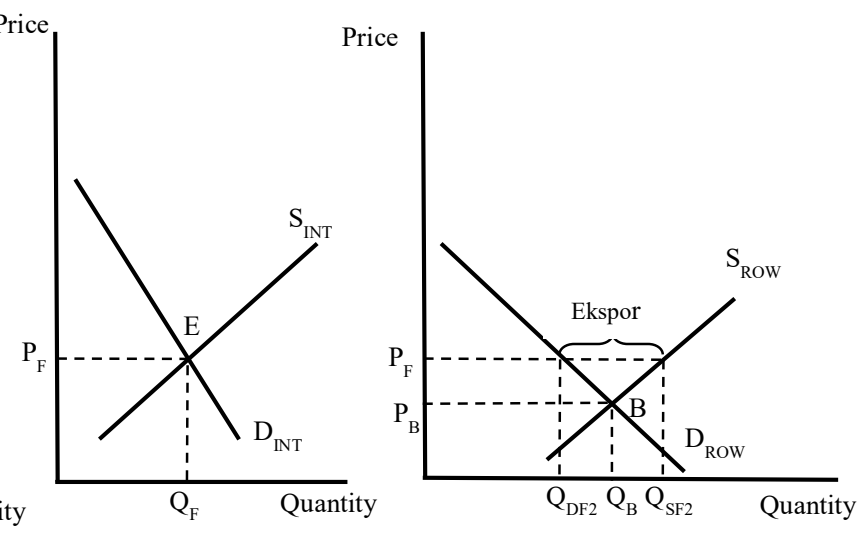

In order to control soybean prices in Indonesia, the government uses tariff instruments. Tariffs are taxes / duties / liabilities imposed on trade commodities that cross the borders of a country. Import tariff is the tax payable on imported commodities. There are three types of tariffs namely ad valorem, specific, and mixed. The ad valorem rate is the rate charged based on a certain fixed percentage of the value of the traded commodity. The specific tariff is the tariff charged at a fixed fixed value per unit of traded goods. A mixed or compound rate is the rate charged against a commodity by combining ad valorem and specific tariffs [16]. Tariffs on soybean commodity imports in Indonesia are subject to ad valorem method in accordance with the price stabilization policy set forth in the Minister of Finance Regulation (PMK). 


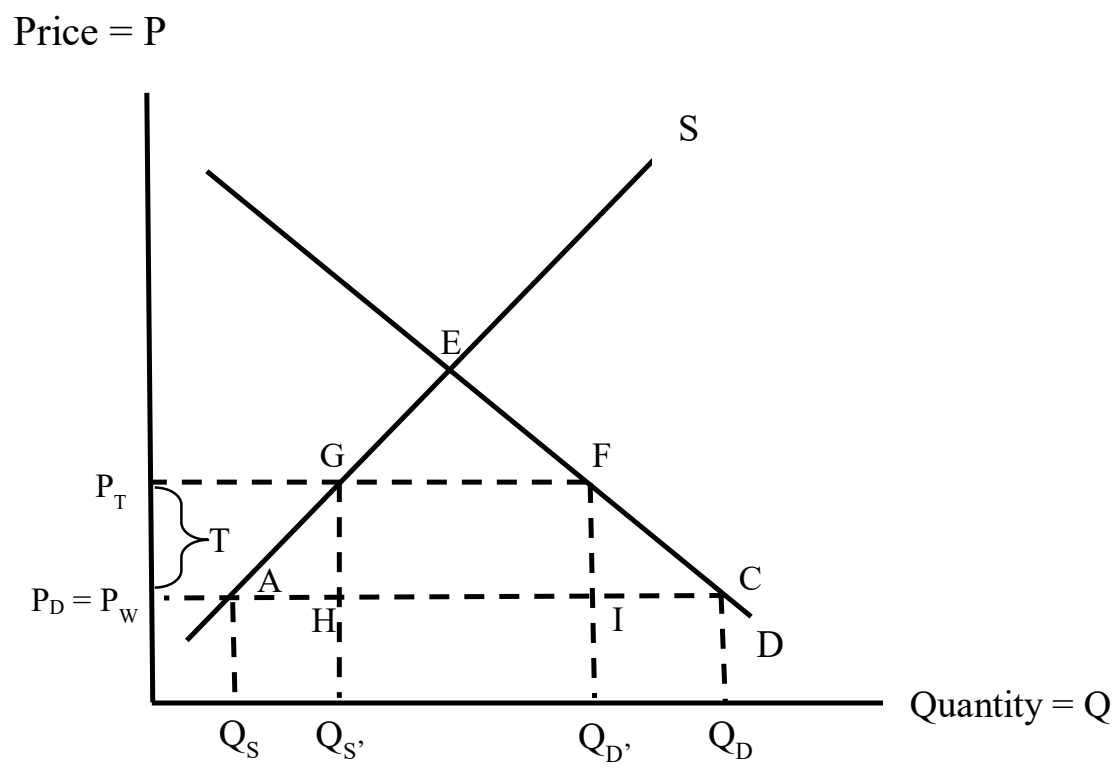

Fig. 7. Tariff Effect on Soybean Prices in Indonesia. Source: Pindyck \& Rubinfeld (1996)

It is assumed that domestic soybean price is equal to world soybean price. If the government imposes a soybean import tariff of T\% then domestic prices will rise to PT which is the sum of world soybean prices and tariffs, domestic production rises to QS', and domestic consumption decreases to QD'. Based on Fig. 7 it can also be seen that there is consumer loss of PTPWCF and producer surplus of PTPWAG, there are government revenue as much as GHIF, and deadweight loss of GAH and FIC. Based on the description above, we can conclude that there is a positive relationship between domestic prices and tariffs.

The impact of international price volatility on the spot market and the soybean futures market in China [24], which is divided into two periods before and after the global financial crisis to determine whether high levels of internationalization affect domestic price volatility in China. The method used is the Vector Error Correction Model (VECM).

The factors that affect the domestic price of cocoa beans in Ghana [2]. Based on the VECM estimation result, it is concluded that the domestic price of cocoa beans is influenced positively and significantly by government policy, domestic price of cocoa beans of the previous year and world price while consumer price index does not significantly affect the domestic price of cocoa beans.

Some researcher used Johansen Multivariate Cointegration and ECM approach with quarterly data from 1990-2006 to analyze factors influencing fluctuation of soybean price in Indonesia $[20,23]$. He found that in the short term the domestic soybean price was positively affected by the domestic price of soybeans a quarter earlier, the nominal exchange rate of the previous quarter, and the GDP of Indonesia. While international soybean prices and import tariffs affect domestic prices positively but not significantly.

The determinants of domestic cocoa beans' domestic prices on the islands of Sumatra and Sulawesi using Engle Granger cointegration and ECM methods [23]. The estimation results show that: (i) in the long term the domestic price of fermented cocoa beans on Sumatra Island is significantly affected by the world price of cocoa beans and the nominal exchange rate. On the island of Sulawesi, the result is significantly influenced by world prices of cocoa beans and coffee prices; (ii) in the long term, the domestic price of non-fermented cocoa beans in 
Sumatera Island is significantly influenced by the world price of cocoa beans. The price of coffee, the nominal exchange rate, and the export volume, while in the central Sulawesi Island is significantly affected by the world price of cocoa beans and Nominal exchange rate [13].

Table 4. Import Dependency Ratio (IDR) of Food Products

\begin{tabular}{|l|c|}
\hline \multicolumn{1}{|c|}{ Independent Variables } & Relationship \\
\hline World Soybean Prices (HKD) & + \\
\hline Soy Import Volume (VIK) & - \\
\hline Nominal Exchange Rate (NER) & + - \\
\hline Gross Domestic Product (GDP) & + \\
\hline Import Rate of Soybean (TI) & - \\
\hline DUMMY BULOG (DB) & \\
\hline
\end{tabular}

Based on the above description and referring to research conducted by several researchers $[7,9,11,16]$, limited by data availability. The variables used in this research are world soybean price, import volume of Indonesian soybean, Nominal exchange rate, gross domestic product (GDP), import tariff of soybean, and dummy variable there is no influence of BULOG as a single importer. The hypothesis of the relationship of variables are presented in Table 3.

\section{Methods of Econometrics and Data Sources}

The general purpose of this study is to know how the influence of determinants on domestic soybean prices. To achieve the above objectives, the stages of research conducted are as follows. The models to be tested are as follows $[7,9,11,16]$ :

$$
\mathrm{LHKI}_{\mathrm{t}}=\propto_{0}+\propto_{1} \text { LHKD }_{t-1}+\propto_{2} \text { LNER }_{t}+\propto_{3} \text { LVIK }_{t}+\propto_{4} L G D P_{t}+\propto_{5} T I_{t}+\propto_{6} D B_{t}+u_{t}
$$

Where LHKI $\mathrm{t}$ : the logarithm of soybean price in Indonesia in the t-period, LHKD: the logarithm of world soybean price in the t-period, $\mathrm{LER}_{\mathrm{t}}$ : nominal exchange rate logarithm in t-period, LVIK $_{t}$ : logarithm of soybean import volume of Indonesia in the period t, LGDPt: logarithm of real GDP of Indonesia in period $t, \mathrm{TI}_{t}$ : variable of tariff of Indonesian soybean import in $\mathrm{t}$-period, $\mathrm{DB}_{\mathrm{t}}$ : dummy variable whether or no influence of BULOG as importer.

In research using time series data, often found data that is not stationary. If this unreformed data is reorganized, it is possible to produce false regression or spurious regression [6]. False regression can occur because the dependent variable and the independent variable used are not stationary and or the formation of the variable is not substantially related [12].

Some cointegration methods, such as those proposed by Engle-Granger and Johansen, require that the variables analyzed are integrated in the same order. In contrast to Pesaran, it allows the variables used to be integrated in I (0), I (1) or mixtures of I (0) and I (1) [15]. Since the initial identification of the stationarity level of the time series data used indicates that the possibility of non-stationary data at the same level, this research uses Bound Testing Cointegration method with Autoregressive Distributed Lag (ARDL) approach by Pesaran [15]. 
The ARDL contains the dynamic effects of a specific model by entering useful lag values to capture data degradation into the model[10]. With a simple transformation, the dynamics of Error Correction Model (ECM) can be derived from ARDL [3, 4, 14]. In addition, the coefficients of long-term estimation and ECM coefficients show the speed of adjustment of a variable in long-term equilibrium.

Before estimating the ARDL model, the optimum lag used should be set first. This lag selection criteria can use Schwarz Bayesian Criterion (SBC) or Akaike Information Criterion (AIC) with minimum value. Selection of the Best ARDL Model and Cointegration Test using Microfit 4.1 software. The ARDL estimation model is as follows:

$$
\begin{aligned}
\Delta \mathrm{LHKI}_{\mathrm{t}}=\propto_{0}+\sum_{\mathrm{i}=1}^{\mathrm{q}} & \propto_{1 \mathrm{i}} \Delta \mathrm{LHKI}_{\mathrm{t}-\mathrm{i}}+\sum_{\mathrm{i}=1}^{\mathrm{q}} \propto_{2 \mathrm{i}} \Delta \mathrm{LHKD}_{\mathrm{t}-\mathrm{i}}+\sum_{\mathrm{i}=1}^{\mathrm{q}} \propto_{3 \mathrm{i}} \Delta \mathrm{LNER}_{\mathrm{t}-\mathrm{i}} \\
& +\sum_{\mathrm{i}=1}^{\mathrm{q}} \propto_{4 \mathrm{i}} \Delta \mathrm{LVIK}_{\mathrm{t}-\mathrm{i}}+\sum_{\mathrm{i}=1}^{\mathrm{q}} \propto_{5 \mathrm{i}} \Delta \mathrm{LGDP}_{\mathrm{t}-\mathrm{i}}+\sum_{\mathrm{i}=1} \propto_{6 \mathrm{i}} \Delta \mathrm{TI}_{\mathrm{t}-\mathrm{i}}+\propto_{7} \mathrm{LHKI}_{\mathrm{t}-1} \\
& +\propto_{8} \mathrm{LHKD}_{\mathrm{t}-1}+\propto_{9} \mathrm{LNER}_{\mathrm{t}-1}+\propto_{10} \mathrm{LVIK}_{\mathrm{t}-1}+\propto_{11} \mathrm{LGDP}_{\mathrm{t}-1}+\mathrm{TI}_{\mathrm{t}-1} \\
& +\propto_{13} \mathrm{DB}_{\mathrm{t}}+\mathrm{u}_{\mathrm{t}}
\end{aligned}
$$

The determination of the existence of cointegration is based on the F-count value compared to the critical value at a certain level of confidence in the bound table. The conclusion of cointegration is based on F-statistic bound table with the following criteria [15]:

- If the F-count is smaller than the lower bound (LB) then it can be concluded that there is no cointegration

- If the F-count is between the lower bound and the upper bound (UB) then the conclusion of cointegration can not be deduced.

- If F-count is above upper bound then it is concluded there is cointegration between variables [15].

To ensure the goodness of fit of the ARDL model a diagnostic test was performed to test for serial correlation, functional, normality, and heteroskedastic specification error in the model and stability test using cumulative sum of recursive (CUSUM) and cumulative sum of squares of recursive residuals (CUSUMQ). The ECM equation of the ARDL model for this study is as follows:

$$
\begin{aligned}
& \Delta L H K I_{t}=\theta_{0}+\sum_{i=1}^{q} \theta_{1 i} \Delta L H K I_{t-i}+\sum_{i=0}^{q} \theta_{2 i} \Delta L H K D_{t-i}+\sum_{i=0}^{q} \theta_{3 i} \Delta L N E R_{t-i}+ \\
& \sum_{i=0}^{q} \theta_{4 i} \Delta L V I K_{t-i}+\sum_{i=0}^{q} \theta_{5 i} \Delta L G D P_{t-i}+\sum_{i=0}^{q} \theta_{6 i} \Delta T I_{t-i}+\theta_{7} D B_{t}+\theta_{8} E C T_{t-1}+\mu_{t}
\end{aligned}
$$

Where $\Delta$ is the first difference operator or the difference between two values of a variable in a consecutive time period, $\mathrm{q}$ is the optimum lag and $\mu$ is the term term equation 3

Table 5. Data and Data Sources

\begin{tabular}{|l|l|l|}
\hline \multicolumn{1}{|c|}{ Variable } & \multicolumn{1}{|c|}{ Description } & \multicolumn{1}{|c|}{ Source } \\
\hline LHKI & $\begin{array}{l}\text { Consumer prices obtained through surveys to soy } \\
\text { retailers in markets across rural areas in Indonesia } \\
\text { include DKI Jakarta in units of Rp / kg converted into } \\
\text { natural logarithms. }\end{array}$ & \\
\hline
\end{tabular}




\begin{tabular}{|l|l|l|}
\hline \multicolumn{1}{|c|}{ Variable } & \multicolumn{1}{|c|}{ Description } & \multicolumn{1}{|c|}{ Source } \\
\hline LHKD & $\begin{array}{l}\text { International soybean prices with HS HS 120100 in } \\
\text { bushel / USD / million tons are converted into natural } \\
\text { logarithms. }\end{array}$ & $\begin{array}{l}\text { International } \\
\text { Monetary Fund } \\
\text { Retrieved from IFS } \\
\text { CD-ROM) }\end{array}$ \\
\hline LNER & $\begin{array}{l}\text { The nominal exchange rate in Rupiah / USD is converted } \\
\text { into a natural logarithm. }\end{array}$ & Bank Indonesia \\
\hline LVIK & $\begin{array}{l}\text { Domestic Imported Soybean Volume in Rp / kg } \\
\text { converted into natural logarithm. }\end{array}$ & Ministry of Trade \\
\hline LGDP & $\begin{array}{l}\text { GDP based on 2000 constant prices or quarterly real } \\
\text { GDP in Billion Rupiah is interpolated to monthly series } \\
\text { using Quadratic Match Sum method using E-VIEWS } \\
7.0 \text { software and converted into natural logarithm. }\end{array}$ & BPS \\
\hline TI & $\begin{array}{l}\text { Tariff on soybean import based on Regulation of the } \\
\text { Minister of Finance in percentage }\end{array}$ & Ministry of Finance \\
\hline DB & $\begin{array}{l}\text { Dummy role variable of BULOG as a single importer. } \\
\text { This BULOG dummy variable uses data 1 before } \\
\text { September 1998 and 0 thereafter. }\end{array}$ & IMF \\
\hline
\end{tabular}

The data used in this study are secondary data derived from the publication of Central Bureau of Statistics (BPS), Bank Indonesia, Ministry of Finance, Ministry of Trade, and IFS CD-ROM. This study uses monthly time series data from 1993 to 2013. Selection of this time range is based on data availability and also to cover research objectives prior to the signing of Letter of Intent by Indonesia and IMF.

\section{Empirical Results}

The stationarity test is performed with the Phillips Peron (PP) Unit Root Test and the results are presented in Table 6 . This test is performed to ensure that no variables are integrated in I (2). In the table, it can be seen that in the stationarity test at the level, all data is not stationary at the level of $95 \%$ confidence level except on the import data of soybeans. Then, the test results of the stationarity at the first difference level indicate that all data has been stationary.

Table 6. Stationary Test Results

\begin{tabular}{|c|c|c|c|c|c|c|}
\hline \multirow{2}{*}{ Variable } & \multicolumn{3}{|c|}{ Level } & \multicolumn{3}{c|}{ First Difference } \\
\cline { 2 - 3 } & \multicolumn{2}{|c|}{ PP Statistics } & \multirow{2}{*}{ Conclusion } & \multicolumn{2}{|c|}{ PP Statistics } & \multirow{2}{*}{ Conclusion } \\
\cline { 2 - 3 } \cline { 5 - 6 } & t-test & t-stat $(\boldsymbol{\alpha}=\mathbf{5 \%})$ & & t-test & t-stat $(\boldsymbol{\alpha}=\mathbf{5 \%})$ & \\
\hline LHKI & -0.12 & -2.87 & Not Stationary & -12.3 & -2.87 & Stationary \\
\hline LHKPI & -1.26 & -2.87 & Not Stationary & -11.0 & -2.87 & Stationary \\
\hline LHKD & -0.19 & -2.87 & Not Stationary & -11.2 & -2.87 & Stationary \\
\hline LVIK & -9.18 & -2.87 & Stationary & - & -2.87 & - \\
\hline LER & -1.82 & -2.87 & Not Stationary & -13.6 & -2.87 & Stationary \\
\hline LGDP & 0.06 & -2.87 & Not Stationary & -8.09 & -2.87 & Stationary \\
\hline TI & -2.2 & -2.87 & Not Stationary & -15.9 & -2.87 & Stationary \\
\hline
\end{tabular}

\subsection{Estimation Results and Analysis of ARDL Model}

Before estimating the ARDL model, the optimum lag used needs to be set first (Enders, 2007). The lag selection criteria use Schwarz Bayesian Criterion (SBC). In the cointegration 
test using Bound Testing Cointegration obtained the F-statistic value of 11,833 while the upper and lower limit of the critical value at $95 \%$ confidence level respectively of 2.39 and 3.38. Since the F-statistic value is greater than the upper limit of the critical value, it can be concluded that there is a long-term relationship on soybean price variables of Indonesia, world soybean price, soybean import volume, exchange rate, GDP, and import tariff. Table 6 shows the selected ARDL model is $\operatorname{ARDL}(1,0,0,0,1,0)$. The best model estimation results are presented as follows:

Table 7. Model ARDL

\begin{tabular}{|l|c|c|}
\hline \multicolumn{1}{|c|}{ Variable } & Coefficient & t-Statistic \\
\hline LHKI(-1) & $0.919^{* * *}$ & 43.902 \\
\hline LHKD & $0.079^{* * *}$ & 3.257 \\
\hline LNER & $0.089^{* * *}$ & 2.930 \\
\hline LVIK & -0.0006 & -0.350 \\
\hline LGDP & $-0.374 *$ & -1.701 \\
\hline LGDP(-1) & 0.352 & 1.553 \\
\hline TI & $-0.001^{* *}$ & -2.167 \\
\hline DB & 0.007 & 0.227 \\
\hline C & -0.281 & -1.018 \\
\hline R-squared & 0.997 & \\
\hline F-statistic & 10771.59 & \\
\hline Prob(F-statistic) & 0.000 & \\
\hline
\end{tabular}

Information: ***) Significant on $\alpha=1 \%, * *)$ Significant on $\alpha=5 \%, *)$ Significant on $\alpha=10 \%$

Diagnostic tests and stability tests are performed to avoid errors in interpretation and conclusions. The diagnostic test was performed by serial correlation and heteroschedasticity test. Table 8 below shows that the ARDL model in this study did not have serial and heteroscedastic correlation problems. The following test results are presented:

Table 8. Diagnostic Test Results

\begin{tabular}{|l|r|r|}
\hline \multicolumn{1}{|c|}{ Test } & \multicolumn{1}{|c|}{ P-Value } & \multicolumn{1}{c|}{ P-Value } \\
\hline $\begin{array}{l}\text { Breusch-Godfrey Serial } \\
\text { Correlation LM Test }\end{array}$ & 3.043 & 0.049 \\
\hline $\begin{array}{l}\text { Heteroschedasticity, Breusch- } \\
\text { Pagan-Godfrey }\end{array}$ & 2.217 & 0.027 \\
\hline
\end{tabular}

Next is the stability test using CUSUM and CUSUMQ. The stability test below has shown that the model under test has been stable as long as the observation period. This can be seen from the CUSUM and CUSUMQ plots in interval critical bound 5\%.

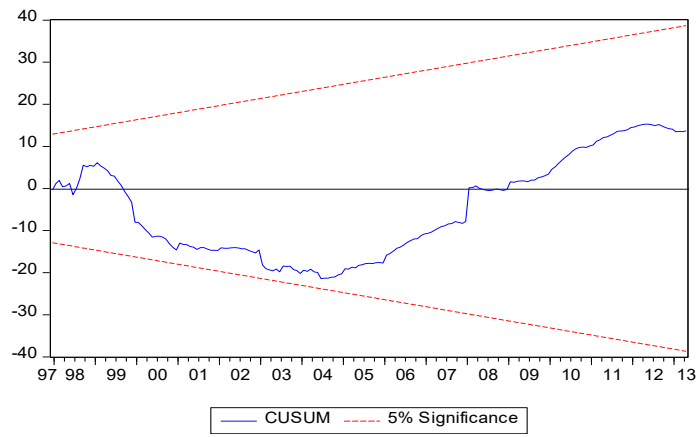


Stability test using Ramsey show the value F-statistic 12.691 and probability value 0.004 , rejected hypothesis no stability. The ECM model contained in Table 9 is the result of the decline of the selected ARDL model. The expected ECM model is a model with significant (negative) and negative ECM coefficients (-1). The significant coefficient of ECM $(-1)$ indicates that there is cointegration on the model and the negative sign ascertain whether there is a convergent correction mechanism against the deviation from the long-term balance. Based on ECM estimation results, it can be seen that there is negative and significant ECM coefficient (-1).

Table 9. ECM Estimated Results

\begin{tabular}{|c|c|c|}
\hline Variable & Coefficient & t-Statistic \\
\hline $\mathrm{D}(\mathrm{LHKD})$ & $0.086^{* *}$ & 2.139 \\
\hline $\mathrm{D}(\mathrm{LNER})$ & $0.088^{* * *}$ & 2.897 \\
\hline $\mathrm{D}(\mathrm{LVIK})$ & -0.002 & -1.267 \\
\hline $\mathrm{D}(\mathrm{LGDP})$ & $-0.376^{* *}$ & -2.159 \\
\hline $\mathrm{D}(\mathrm{TI})$ & 0.0001 & 0.061 \\
\hline $\mathrm{D}(\mathrm{DB})$ & -0.012 & -0.330 \\
\hline CointEq(-1) & $-0.081^{* * *}$ & -9.053 \\
\hline
\end{tabular}

The above results show that in the short term the world soybean price (LHKD), exchange rate (LNER) and GDP variables in the t-period affect the domestic soybean prices significantly with each coefficient of $0.086,0.088$. and -0.376 respectively. While the volume of imports (LVIK) in the t-period did not significantly affect the domestic soybean prices. However, import tariffs have a negative and significant influence that is inconsistent with the theory. Then, despite having a positive influence, but the role of BULOG as a single importer was not significant on the price of soybeans in the short term. The ECM variable coefficient $(-1)$ shows the number -0.081 . This negative sign indicates a convergent correction mechanism for deviations from the long-term equilibrium in the model.

\subsection{Results and Analysis Long Term Model}

The long-term coefficients are calculated from the short-run coefficients of the ARDL Model. The coefficients are presented in Table 10 below.

Table 10. Long Term Coefficient

\begin{tabular}{|c|c|c|}
\hline Variable & Coefficient & t-Statistic \\
\hline LHKD & $0.985^{* * *}$ & 4.868 \\
\hline LNER & $1.097^{* * *}$ & 3.332 \\
\hline LVIK & -0.008 & -0.336 \\
\hline LGDP & -0.266 & -0.660 \\
\hline TI & $-0.016^{* *}$ & -2.356 \\
\hline DB & 0.092 & 0.224 \\
\hline C & -3.468 & -1.092 \\
\hline
\end{tabular}

In the long term, the world soybean price and exchange rate variables have a positive and significant influence with each coefficient of 0.985 and 1.0297. However, soybean import volume and GDP variables did not have a significant effect. Just as in the short term, import tariffs have a negative and significant effect in the short term. This is not as expected. While in the long run, the role of BULOG as a single importer empirically does not have a significant effect on the decline in soybean prices.

The results confirm that world soybean prices have a positive and significant effect both in the short and long term. From the short-term results obtained if there is $1 \%$ change in 
world soybean prices will increase domestic soybean prices by $0.086 \%$. Meanwhile, in the long term, if there is an increase in world soybean price of $1 \%$ it will cause the increase in domestic soybean prices by $0.985 \%$. Thus, it can be said that there is a world soybean price transmission on Indonesian soybean prices. This discovery is in line with the results of research [23].

The results of the study must have been predictable because as previously described, more than $60 \%$ of Indonesia's soybean consumption is obtained through import. Thus, this dependence on imports causes domestic soybean prices to be severely affected by fluctuations in soybean prices abroad, especially US soybean prices. The increase in US soybean prices, for example, occurred in 2007-2008 caused by the decline in soybean production in the United States because farmers prefer to grow maize as raw material for biodiesel [18]. In addition, the increase in soybean prices in the United States also occurred in 2012 caused by bad weather and cause crop failure [22].

The nominal exchange rate has a positive and significant influence on the long term and the short term. Empirical results in the short-term show that if there is $1 \%$ depreciation of the rupiah against the US dollar then domestic soybean prices will rise by $0.088 \%$. With soybean import policy, every fluctuation of rupiah exchange rate to US dollar, soybean price in domestic also will fluctuate.

Positive impacts are seen in empirical results that indicate incompatibility with the theory. However, long-term and short-term regression results indicate that the impact of import volume on soybean prices is not significant either in the short or long term. As mentioned earlier, soybean import is one of the government's policies in order to fulfill public consumption as well as one of the government's efforts to stabilize domestic soybean prices.

Increased real incomes will increase purchasing power so as to increase public demand for these goods and services which ultimately increase the prices of these goods and services. However, despite having a positive influence, the GDP variable has no significant effect on soybean prices.

Based on the results of this study, in the long term and short term, soybean import tariff has no effect. Meanwhile, in the long term, if there is a decrease of soybean import tariff by $1 \%$ it will decrease domestic soybean price by $0.016 \%$. This empirical study suitable to the theory. Based on this research, BULOG's role as a sole importer has positive and insignificant influence in long term and short term. This indicates that government intervention through BULOG does not have a significant impact in lowering soybean prices.

\section{Conclusions and Policy Implication}

Fulfilling national consumption of soybeans depends largely on soybean imports. Therefore, external turmoil has a greater effect on soybean prices in the country. The results of the analysis in this study, confirm the statement. By using Bound Testing Cointegration method with ARDL approach, it can be seen that in long term the world soybean price and exchange rate variable have positive and significant influence. Then, the volume variables of soybean import, GDP, and BULOG role as a single importer have no significant effect. However, import tariffs in the t-period have a negative and significant impact. Meanwhile, in the short term the world soybean price variables in the t-period and exchange rate affect the domestic soybean prices positively and significantly. Furthermore, the variable volume of soybean imports, GDP, and the role of BULOG as a sole importer in the t-period does not affect the domestic soybean price significantly. Just as in the long run, the t-period import tariff has a negative and significant effect. The results obtained on the relationship between domestic soybean prices and tariffs do not show conformity with the theory. However, if we look at 
the best ARDL model results, it can be seen that the import tariff of soybeans of a previous period has a positive and significant influence on domestic soybean prices. This indicates a lag in the implementation of the policy.

The ECM variable coefficient (-1) denotes the number -0.081 . This negative sign indicates a convergent correction mechanism for deviations from the long-term equilibrium in the model. From the analysis results can be concluded that the intervention that has been done by the government in domestic soybean price control at this time, that is the import policy has not been effective in controlling domestic soybean price. While the soybean tariff, takes a period to affect the price of soybeans in the country. Then, the authority of BULOG has no significant effect. In other words, the role of BULOG as a single importer of soybean commodities has not been effective in intervening soybean prices. In the meantime, it is expected that there will be a quick response by the government on various information of soybean commodity as an effort to control soybean price and it is expected that the effectiveness of soybean market operation will be improved in the future. In addition, of course, the role of BULOG is certainly can be improved through the improvement of human resources capabilities.

\section{References}

1. B. Arifin, Diagnosis Ekonomi Politik Pangan dan Pertanian. Jakarta: Raja Grafindo Persada (2007).

2. Amendofu, M. Determination of Cocoa Producer Price in Ghana. Africa: Kwame Nkrumah University of Science and Technology (2009)

3. Banerjee, S, Recovery and Growth in Indonesia Industry: Element of A Future Policy Framework. UNSFIR Working Paper. Jakarta (2002)

4. Baulch, B. Testing for Food Market Integration Revisited. The Journal of Development Studies, 33(4), 512. (1997).

5. Enders, W., Applied Econometric Time Series (3rd ed.). New York: N.Y. John Wiley \& Sons (2007).

6. Gujarati, D. N., \& Porter, D. C.,Basics Econometrics (5th ed.). New York: The McGrawHill Companies, inc. (2009)

7. Hutabarat, B., Analisis Saling Pengaruh Harga Kopi Indonesia dan Dunia. Jurnal Agro Ekonomi. , 24(1), 21-40 (2006)

8. Jayasuriya S, Mudbhary P, Broca SS., Food Price Spikes, Increasing Volatility and Global Economic Shocks: Coping with Challenges to Food Security in Asia: A Comparative Regional Study of the Experiences of Ten Asian Economies. Bangkok: Food and Agricultural Organization (FAO) of the United Nations Regional Office for Asia and the Pacific (2012)

9. Joiya, S. A., \& Shahzad, A. A, Determinants of High Food Prices - The Case of Pakistan. Pakistan Economic and Social Review, 51(1), 93-107 (2013).

10. Laurenceson, J., \& Chai, J.,. Financial Reform and Economic Development in China. Inggris: Edward Elgar Publishing (2003)

11. Luo, F. Influence of External Shocks on Price Fluctuation of Agricultural Products of China: An Empirical Analysis Based on the VAR Model. (Q. Zhou, Ed.) Applied Economics, Bussines, and Development, 374-381 (2011). 
12. Ekananda, M., Time Series Analysis for Research in Economy and Business, $2^{\text {nd }}$ Edition, Publisher : Mitra Wacana Media, Jakarta (2016)

13. Ekananda, M., and Parlinggoman, D.J., The Role Of High-Tech Exports And Fdi On Economic Growth, European Research Studies Journal Volume XX, Issue 4A, (2017)

14. Nkang, N. M., Ndifon, H. M., \& Odok, G. N., Price Transmission and Integration of Cocoa and Palm Oil Market in Cross River State, Nigeria: Implication of Rural Development. Agriculture Journal, 2(4), 457-463 (2007)

15. Pesaran, M. H., Shin, Y., \& Smith, R. J., Bound Testing Approaches to the Analysis of Level Relationship. Journal of Applied Econometrics, 16, 289-326 (2001).

16. Pugel, T. A., International Economics (12 ${ }^{\text {th }}$ ed.). New York: The McGraw-Hill Companies (2004).

17. Sumaryanto. Retail Price Volatility of Some Food Commodities Using ARCH/GARCH Model. Jurnal Agro Ekonomi, 27(2), 135-163 (2009).

18. Supadi, Dampak Impor Kedelai Berkelanjutan terhadap Ketahanan Pangan. Analisis Kebijakan Pertanian, 7(1), 87-102 (2007).

19. Timmer CP., Managing Price Volatility: Approaches at the Global, National, and Household Levels. Stanford Symposium Series on Global Food Policy and Food Security in the 21st Century. California: Standford University (2011).

20. Suryanto, T., Implementation of Fair Value Accounting on Agency Problem Contract Mudharaba in Islamic Finance, International Journal of Economic Perspectives, 2015, Volume 9, Issue 4, 94-102 (2015)

21. Turner, P., \& Dack, J. V., Measuring International Price and Cost Competitivenes. Basle: Bank for International Settlements (1993).

22. Westcott, Paul C., \& Jewison, Michael, Weather Effects on Expected Corn and Soybean Yields. Florida: USDA (2013).

23. Widodo, S., Tesis: The Analysis of Long Term and Short Term Factors Affecting the Domestic Price of Soybean. Jakarta: Universitas Indonesia (2010).

24. Zhao, Y., Yang, M., Zhang, Y., \& Qi, C. Impact on the Chinese Soybean Markets from International Prices Volatility: Empirical Study Based on VEC Model. African Journal of Agriculture Research, 05(15), 1943-1950 (2010) 